\title{
AMERYKAŃSKIE OBRAZY W PAMIĘCI WOJCIECHA KARPIŃSKIEGO W KONTEKŚCIE BADAŃ NEUROLOGICZNYCH ANTONIO DAMASIO
}

BARBARA TRYGAR

Jakie mechanizmy odpowiadają za tworzenie obrazów w pamięci? Czym jest pamięć? Jaki jest związek między pamięcią a językiem i kulturą? Czy istnieje jakiś ścisły związek między neurobiologią a sztuką? Odpowiedzi na te pytania udzielił portugalski neurolog Antonio Damasio, autor m.in. prac: Descartes' Error. Emotion, Reason and the Human Brain (Putnam 1994; wyd. pol. Błąd Kartezjusza. Emocje, rozum i ludzki mózg, Poznań 1994), Looking for Spinoza: Joy, Sorrow, and the Feeling Brain (Harcourt 2003; wyd. pol. W poszukiwaniu Spinozy: radość, smutek i czujący mózg, Poznań 2003), Self Comes to Mind: Constructing the Conscious Brain (Pantheon 2010; wyd. pol. Jak umysł zyskał jaźń. Konstruowanie świadomego mózgu, Poznań 2012), The Strange Order of Things. Life, Feeling, and the Making of Cultures (Pantheon 2018; wyd. pol. Dziwny porządek rzeczy. Życie, uczucia i tworzenie kultury, Poznań 2018). W szczególności w swojej ostatniej pracy zaakcentował, że neurobiologia i kultura prowadzą ze sobą twórczy dialog. Amerykański fizyk Leonard Mlodinow napisał, że: „Prawie ćwierć wieku po Błędzie Kartezjusza Antonio Damasio ponownie to zrobił - przeprowadził wielką eksplorację nierozerwalnych związków między umysłem, ciałem i źródłem ludzkich uczuć. Zabiera czytelnika w podróż, która zaczyna się od organizmów jednokomórkowych i mózgu, a kończy na pochodzeniu świadomości i ludzkich kultur"'. Manuel Castells, profesor socjologii

${ }^{1}$ Z recenzji Leonarda Mlodinowa książki A. Damasio: Dziwny porządek rzeczy. Życie, uczucia i tworzenie kultury, tłum. A. Jankowski, Poznań 2018, s. 336; 
z University of California w Berkeley, dodał, że prace Damasio dostarczają pojęć, języka i wiedzy dla spójnego wyjaśnienia wzajemnych oddziaływań między naturą i kulturą, w których tkwi sedno kondycji człowieka. Badacz odsłania kody i zasady, które czynią nas ludźmi. Po długim okresie rozczłonkowania nauki proponuje paradygmat, który ponownie ją scala - ponad podziałami istniejącymi między różnymi dziedzinami, wokół badań sieci umysłu w połączeniu z sieciami jego biologicznego i społecznego podłoża² Powstawanie kultur jest możliwe dzięki wysoko rozwiniętemu intelektowi, unikatowej zdolności porozumiewania się językiem, umiejętności tworzenia społeczności - wspólnoty ludzi.

Podczas konferencji „Art and the New Biology of the Mind”, zorganizowanej przez Italian Academy na Columbia University 24 marca 2006 roku, Damasio konstatował: powstanie kultur, dzieł sztuki, systemów etycznych, religijnych bądź społecznych jest możliwe dzięki istotom twórczym, a tym, co kieruje ich rozwojem, są afekty, emocje, procesy odczuwalne, wyobraźnia $^{3}$. Zakorzenienie i istnienie artefaktów kultury zależy od długości ich przechowywania w pamięci. Według Damasio człowiek przechowuje w pamięci nie tylko dane fizyczne określonego przedmiotu czy obiektu, które umożliwiają zrekonstruowanie jego kształtu, koloru, zapachu; przechowuje również aspekty motorycznego zaangażowania swojego ciała w procesie postrzegania istotnych cech tego obiektu: emocjonalną reakcję na obiekt oraz szeroko pojęty stan fizyczny i umysłowy w czasie jego postrzegania. Odtwarzanie działań przystosowawczych ciała, które towarzyszą interakcji z przypomnianym sobie obiektem, wytwarza sytuację podobną do tej, która istniała, kiedy spostrzegał go bezpośrednio ${ }^{4}$. Jak badacz dowodzi w książce Dziwny porządek rzeczy...:

Informacje pochodzą z: Centrum Prasowe PAP, nota z 9.11.2018.

2 Antonio Damasio in conversation with Manuel Castells [wywiad], 6.02.2017, Central Library, Los Angeles.

3 A. Damasio, Conference. Art and the New Biology of the Mind [wykład], 24.03.2016, The Italian Academy (Columbia University).

4 Idem, Błąd Kartezjusza. Emocje, rozum i ludzki mózg, tłum. M. Karpiński, Poznań 1999, s. 108-117, 233-250. Zob. też: idem, Creativity, Imagination and Innovation [wykład], 13.01.2014, Ross Institute Summer Academy, East Hamptin (NY); D. Schacter, Searching for Memory: The Brain, the Mind, and the Past, New 
[...] kiedy powstał umysł, ale zanim stał się kulturowy w obecnie przyjętym znaczeniu tego słowa, musiał zostać wzbogacony o nowe cechy, które okazały się imponujące. Do tych nowych funkcji należały opierająca się na obrazach pamięć - zdolność rejestrowania, odtwarzania i łączenia ze sobą faktów i zdarzeń, poszerzona wyobraźnia, pogłębione rozumowanie i zdolność myślenia symbolicznego, umożliwiająca tworzenie narracji niewerbalnych, a także zdolność tłumaczenia niewerbalnych obrazów i symboli na kody językowe. Ta ostatnia torowała drogę do wynalezienia czegoś, co pełni decydującą rolę w tworzeniu kultur równoległych do niewerbalnych narracji werbalnych. „Genetycznymi”, umożliwiającymi rozwój narzędziami tych narracji stały się alfabety i gramatyka. Ukoronowaniem tego było wynalezienie pisma, co dawało dostęp do instrumentarium inteligencji twórczej, inteligencji zdolnej do podejmowania pod wpływem uczuć wyzwań homeostatycznych i do wykorzystywania homeostatycznych szans ${ }^{5}$.

Homeostaza oznacza skoordynowane i w pewnym stopniu zautomatyzowane reakcje fizjologiczne, konieczne do zapewnienia stałości w czynnościach organizmu. Odgrywa ważną rolę w działaniu świadomości, która ma za zadanie odbierać i przetwarzać bodźce ze środowiska zewnętrznego i odpowiednio na nie reagować. Dzięki świadomości dochodzi do połączenia regulacji procesów życiowych i tworzenia obrazów. Świadomość jest zawsze obecna w procesie tworzenia, ale nie jest w pełni odpowiedzialna za kreatywność i zdolność tworzenia idei, artefaktów, które potrzebują obszernej pamięci faktów, pamięci roboczej, zdolności do rozumowania, wyobraźni i języka. Przytoczę fragment utworu Wojciecha Karpińskiego, potwierdzający związek między świadomością, pamięcią i wyobraźnią:

Nabokov wydaje mi się jednym z nielicznych artystów, którym udało się choćby w części dać odpowiedź na te kluczowe dla współczesnej kultury

York 1996; F. Bartlett, Remembering: a Study in Experimental and Social Psychology, Cambridge 1954.

5 A. Damasio, Dziwny porzadek rzeczy, op. cit., s. 212-213. Por. A. Damasio, H. Damasio, Dziwny porzadek rzeczy. Homeostaza, uczucia i powstawanie kultur [wykład], 13.09.2017, Copernicus Center for Interdisciplinary Studies; A. Damasio, What is the Strange Order of Things? [wykład], 31.07.2018, Copernicus Center for Interdisciplinary Studies. 
kwestie. Najpierw dostrzegałem u niego przede wszystkim wyobraźnię obracającą się w pustce, stwarzającą całkowicie fikcyjne twory. Stopniowo poza eksperymentami zobaczyłem treść - artystyczną rzeczywistość rozpaloną przez wyobraźnię. Związek między osobowością autora a stwarzanym przez niego światem stanowi problem bardzo delikatny... ${ }^{6}$.

Świadomość jest źródłem wiedzy o tym, że obrazy istnieją w człowieku, który je tworzy. To ona układa je w ten sposób, aby podmiot widział owe obrazy z własnej perspektywy. „Obrazy” to wzorce umysłowe o strukturze złożonej z elementów dowolnej modalności zmysłowej, wzrokowej, słuchowej czy somatosensorycznej ${ }^{7}$. Powstają w momencie, kiedy człowiek wchodzi w relacje z otoczeniem, z innym człowiekiem, jak również wtedy, kiedy przywołuje dane obiekty ze swojej pamięci.

W Central Parku Karpiński przedstawia obrazy, które powstały w pamięci bohatera podczas podróży do Stanów Zjednoczonych; jak podkreśla narrator, była to podróż w przyszłość, ku temu, co jeszcze nieodkryte, ale także podróż w przeszłość, odkrywanie swojego „Ja”:

Dlatego, jak sądzę, nie ma jednolitej lekcji amerykańskiej kultury, jednorodnej mapy Ameryki. Uwaga oglądającego kieruje się ku kilku motywom, wybranym subiektywnie, lecz wpisanym w amerykański horyzont, rozwijającym tu swój sens. [...] Budowałem trwanie w czasie, genealogię i perspektywy. Wyprawa do Nowego Świata to nie tylko podróż w przestrzeni, ale też podróże w czasie, lekcja geografii i zarazem lekcja języka. [...] Wyjeżdżając, miałem przekonanie, że to, co potrafię opowiedzieć, jeżeli potrafię, to tylko pierwsza wersja, tylko szkic mapy Ameryki. Zamknąć wrażeń z Central Parku nie umiem. Nie zamknęły się przecież. Jeszcze Ameryka nie została oswojona, jeszcze powroty dają radość, trwa pamięć, a wyobraźnia wybiega naprzód. Jeszcze nie koniec podróży ${ }^{8}$.

Jak podkreśla pisarz, była to podróż inicjacyjna, wchodzenie we wspólnotę, podróż ku źródłom pamięci, wyobraźni, języka. Było to spotkanie z innymi artystami, którzy pozwolili mu w nowych perspektywach zobaczyć

6 W. Karpiński, W Central Parku, Warszawa 2010, s. 66.

7 A. Damasio, Tajemnica świadomości. Ciało i emocje wspóttworza świadomość, tłum. M. Karpiński, Poznań 2000, s. 342.

8 W. Karpiński, op. cit., s. 38. 
malarstwo Davida Hockney’a, usłyszeć wiersz Vladimira Nabokova czy wsłuchać się w dźwięki Rigoletta Giuseppe Verdiego. Obrazy, które bohater przywołuje w swojej pamięci, są nie tylko obrazami wizualnymi, ale także słuchowymi. Ukazują materialne, jak również czasowo-przestrzenne aspekty bytów.

Warto w tym miejscu przywołać rozważania współczesnych badaczy dziedzin interdyscyplinarnych nad pamięcią. Astrid Erll w książce Media and Cultural Memory zaproponowała interesujący zwrot „travelling memory”, zaczerpnięty z koncepcji „wędrujących kultur” Jamesa Clifforda oraz „życia w ruchu” („in Bewegung leben”) Aby’ego Warburga ${ }^{9}$, który analizował transformacje motywów artystycznych i wizualnych w europejskiej kulturze pamięci. Niemiecka badaczka dowiodła, że pamięć jest w nieustannym ruchu między różnymi kulturami (w tym przypadku są to kultury polska i amerykańska), dyscyplinami (literatura i neurologia) czy mediami (słowo i obraz) $^{10}$. Ta wzajemna koegzystencja, u której podstaw znajduje się ruch w stronę zapamiętywania i tworzenia obrazów z przeszłości, umożliwia zaistnienie określonego typu wypowiedzi literackiej jako komunikatu: pamięć komunikacyjna zapewnia dziełu sztuki utrwalanie określonych wydarzeń i przekazuje te obrazy czytelnikom. Jak pisze Wojciech Karpiński:

9 Aby Warburg podjął ważne zagadnienie upamiętniania doświadczeń, wydarzeń, zjawisk, „życia w ruchu” za pomocą słów i obrazów; jego dzieło Atlas obrazów Mnemosyne ciągle inspiruje badaczy oraz artystów do nowych odczytań i propozycji samodzielnego zakończenia ze strony odbiorcy. Warto w tym miejscu przypomnieć Kulturwissenschaftliche Bibliothek Warburg - Bibliotekę Kulturoznawczą Aby'ego Warburga, która pozostawała w ciągłym ruchu (Warburg podróżował ze swoją biblioteką, początkowo był to zbiór 3-5 tys. woluminów) - jej układ zależał od asocjacji autora. Warburg określał ją często jako bibliotekę en globe - „sieć neuronalnych połączeń"; zob. T. Majewski, Kinematyka pamięci: Aby Warburg i Jean-Luc Godard, https://www.academia.edu/3776503/Kinematyka_pami\%C4\%99ci_Aby_ Warburg_i_Jean_Luc_Godard [dostęp 21.03.2020]; P.A. Michaud, Aby Warburg and the Image in Motion, transl. S. Hawkes, New York 2004. Interesujące materiały na temat twórczości niemieckiego historyka sztuki znajdują się w The Warburg Institute (University of London).

${ }^{10}$ M. Saryusz-Wolska, Posłowie. Wędrówka pamięci według Astrid Erll, [w:] A. Erll, Kultura pamięci. Wprowadzenie, tłum. A. Teperek, Warszawa 2018, s. 269-277. 
„Podróże są wyzwaniem dla wyobraźni - nowe doznania domagają się nowych skojarzeń, nowych słów”"l. Pamięć pozostawia w czytelniku wrażenie czyjejś obecności, ponad czasem i przestrzenną odległością. Astrid Erll na założonej w 2011 roku Frankfurt Memory Studies Platform (FMSP) dowodziła, że narracja jest jednym z kluczowych trybów zapamiętywania. Aby poradzić sobie ze złożonością narracji i pamięci, konieczne jest połączenie wiedzy specjalistycznej (klasycznej i postklasycznej) narratologii $\mathrm{z}$ innymi dyscyplinami: psychologią, sztuką, literaturą ${ }^{12}$. Grupa badaczy Gießen, na czele z niemieckim historykiem Christophem Cornelißenem, autorem programowej definicji Erinnerungskulturen (kultury pamięci) ${ }^{13}$,

11 Ibidem, s. 41.

12 FMSP powstało $\mathrm{z}$ inicjatywy Forschungszentrum füf Historische Geistewissenschaften (FzHG), do którego należą badacze zajmujący się zagadnieniem pamięci (przede wszystkim w kontekście kulturowym) z różnych dyscyplin naukowych: historycy, socjologowie, literaturoznawcy, psychologowie, medioznawcy. Warto przypomnieć trzy najważniejsze obszary zainteresowań Astrid Erll w tematyce pamięci: 1. Transcultural Memory; 2. Mediality of Memory; 3. Memory and Narrative. Zob. Frankfurt Memory Studies Platform, http://www.memorystudies-frankfurt.com/ [dostęp 21.03.2020].

${ }^{13}$ Chociaż termin „kultura pamięci” pojawił się w języku naukowym dopiero w latach 90. XX wieku, stał się obecnie kluczowym terminem we współczesnych badaniach historii kultury (zob. C. Cornelißen, Was heißt Erinnerungskultur? BegriffMethoden-Perspektiven, "Geschichte in Wissenschaft und Unterricht” 2003, heft 54, s. 548-563), „w odniesieniu do całości naukowego wykorzystania historii w przestrzeni publicznej - przy użyciu najróżniejszych środków i do najróżniejszych celów" (H.G. Hockerts, Zugänge zur Zeitgeschichte. Primärerfahrung, Erinnerungskultur, Geschichtswissenschaft, [w:] Verletztes Gedächtnis. Erinnerungskultur und Zeitgeschichte im Konflikt, Hrsg. von K.H. Jarausch, M. Sabrow, Frankfurt am Main 2002, s. 39-73). Christoph Cornelißen dodaje jeszcze: „Der Begriff umschließt mithin neben Formen des ahistorischen oder sogar antihistorischen kollektiven Gedächtnisses alle anderen Repräsentationsmodi von Geschichte, darunter den geschichtswissenschaftlichen Diskurs sowie die nur "privaten « Erinnerungen, jedenfalls soweit sie in der Öffentlichkeit Spuren hinterlassen haben"; C. Cornelißen, Erinnerungskulturen. Version 2.0, 22.10.2012, Docupedia-Zeitgeschichte. Begriffe, Methoden und Debatten der zeithistorischen Forschung, DOI: 10.14765/zzf.dok.2.265. v2. Zob. też: C. Cornelißen, S. Fisch, A. Maas, Grenzstadt Straßburg: Stadtplanung, 
podkreśliła w swoich badaniach, że mamy do czynienia z zagadnieniem „nieparadygmatycznym, interdyscyplinarnym, które wyłoniło się z socjologii, historii, krytyki literackiej, antropologii, psychologii, historii sztuki, nauk politycznych i innych dziedzin"14, ze swoistym cultural memory studies. Aleida i Jan Assmannowie pod koniec lat 80. XX wieku na Uniwersytecie w Heidelbergu prowadzili interdyscyplinarne seminaria badawcze poświęcone problematyce kultury pamięci oraz archeologii komunikacji literackiej. Wyniki pracy nad pamięcią przedstawili w zredagowanej wspólnie z Toniem Hölscherem książce Kultur und Gedächtnis (1988). W definiowaniu pamięci należy mieć na uwadze cały zespół czynników społeczno-kulturowych i oddziaływanie otaczającej rzeczywistości na podmiot. Pamięć kształtuje się w indywiduum przez fakt życia w danej społeczności, która na ów podmiot wpływa i oddziałuje. Pamięć jest wytworem kulturowym, czyli tym, co społeczność w toku międzypokoleniowego trwania i komunikacji tworzy ${ }^{15}$. Ważne są katalizatory, decydujące o wyborze takiego, a nie innego fragmentu rzeczywistości. W pamięci kulturowej nie zwraca się uwagi na całą przeszłość, tylko na wybrane jej aspekty.

Antonio Damasio w książce Tajemnica świadomości. Jak ciało i emocje współtworza świadomość, posługując się metaforą zaczerpniętą z dziedziny sztuki, poruszył interesujące zagadnienie: w jaki sposób powstaje „film w mózgu” i jak umysł tworzy poczucie, że człowiek jest posiadaczem i widzem tego filmu:

Zawsze intrygował mnie ten szczególny moment: siedzimy na widowni, otwierają się prowadzące na scenę drzwi i w jej światła wychodzi artysta.

kommunale Wohnungspolitik und Öffentlichkeit 1870-1940 (= Saarbrücker Studien zur interkulturellen Kommunikation, Bd. 2), St. Ingbert 1997; C. Cornelißen, Historische Identitätsbildung im Bindestrichland Nordrhein-Westfalen (= Stiftung Bibliothek des Ruhrgebiets, Schriften, Bd. 26), Essen 2008.

14 J. Olick, J. Robins, Social Memory Studies. From "Collective Memory" to the Historical Sociology of Mnemonic Practices, "Annual Review of Sociology” 1989, Vol. 24, s. 105.

15 Aleida i Jan Assmannowie w działaniach społeczności wyróżnili cztery rodzaje pamięci: 1. pamięć mimetyczną, 2. pamięć rzeczy, 3. pamięć komunikatywną, 4. pamięć kulturową. Zob. A. Rajewski, Rozważanie na temat Assmanowskiej teorii pamięci, „Rocznik Antropologii Historii” 2013, R. 3, nr 1(4), s. 188, 190. 
Albo też, przyjmując inną perspektywę, chwila, kiedy oczekujący w półmroku artysta dostrzega te same uchylające się drzwi, za którymi rozbłyskają światła, pojawia się scena i publicznośćć

Wojciech Karpiński w książce W Central Parku podejmuje refleksję nad procesem powstawania dzieła poprzez wzrokową reprezentację zwykłych przedmiotów. Można zauważyć, że percepty wzrokowe, obrazy mentalne, ślady pamięciowe powstają w ramach jednego systemu wizualnego, czemu zawdzięczają wspólną obrazową naturę. W ich powstawaniu u bohatera włączają się poszczególne podsystemy: sensoryczny, uwagowy, pamięciowy, wyobrażeniowy:

W tych momentach na wewnętrznym ekranie przebiegają obrazy nie tylko barwniejsze niż zazwyczaj, ale też prawdziwsze - bliżej związane ze światem i ze sferą prywatności. [...] Dostrzegając wielowymiarowość świata, widzę lepiej siebie. Opada martwa skorupa słów. Przez pewien czas myślę nie pojęciami, lecz wartko toczącą się rzeką obrazów. Jak ją utrwalić, jak wpleść w nurt codziennego doświadczenia? „Podwójne jest płynięcie, dwoisty ruch i szum”. A jednak zespolenie, choćby ułamkowe, obu nurtów jest możliwe. $\mathrm{W}$ pamięci trwają minione chwile intensywnego widzenia ${ }^{17}$.

Według Damasio posiadać umysł to znaczy być zdolnym do tworzenia neuronowych reprezentacji, które mogą stać się obrazami; te z kolei mogą podlegać takim działaniom jak myślenie i wpływać na zachowanie czy podejmowane decyzje $\mathrm{e}^{18}$. Istotą neurobiologii według portugalskiego

16 A. Damasio, Tajemnica świadomości, op. cit., s. 11 i 19. W artykule używam słów-kluczy zaczerpniętych z prac Damasio: „pamięć”, „wzorzec”, „świadomość rdzenna”, „świadomość rozszerzona”, „proto-»Ja«”, „»Ja« rdzenne”, „»Ja« autobiograficzne". Warto przypomnieć też pracę Behavioral and Brain Ricka Grusha, w której autor opisuje teorię zachowań motorycznych. Zachowania te Grush korelował z percepcją wzrokową oraz wyobraźnią motoryczną i wizualną. Za podstawową kategorię uznał emulator, hipotetyczny mechanizm neuronalny, który kopiuje programy motoryczne i percepcyjne podczas wykonywania ruchu przez człowieka. Wzrost zainteresowania wyobraźnią wizualną i motoryczną jest widoczny również w badaniach Davida Milnera i Melvyna Goodale’a.

17 W. Karpiński, op. cit., s. 10.

18 W artykule odwołuję się do badań powstawania obrazów teraźniejszości, przeszłości i przyszłości w umyśle człowieka zawartych w książce Damasio: Błąd 
uczonego jest proces, dzięki któremu reprezentacja neuronowa - złożona z biologicznych przekształceń i dokonująca się w obwodach neuronowych przyczynia się do powstawania obrazów w mózgu. Przebieg ten umożliwia niewidzialnym mikrostrukturalnym zmianom w obwodach nerwowych (w ciałach komórek, dendrytach, aksonach i synapsach) przyjęcie charakteru neuronowych reprezentacji, które stają się obrazami doświadczeń człowieka. Damasio wskazuje, że głównym zadaniem mózgu jest odbiór bodźców płynących ze środowiska, w którym znajduje się podmiot, jak również analizowanie, ocena działań podejmowanych decyzji przez ten podmiot. Warto w tym miejscu ponownie zacytować fragment utworu Karpińskiego:

Migocące neonami drapacze tworzyły wspaniałą scenerię. Wytryskująca ku górze linia nie stanowiła zamknięcia parku, otwierała napowietrzną Operę ku nowym przestrzeniom na całe miasto, na Amerykę. Jeżeli muzyka jest przede wszystkim rozwijaniem się dźwięku w czasie, to muzyka w Central Parku była także oswajaniem przestrzeni. Każdy z nas, słuchających, mógł udać się w innym kierunku. Mógł być tylko tu, w czystej materii dźwięku, mógł być też tylko tu, na nowojorskim jarmarku, przechadzać się po wielkomiejskim odpuście sztuki. Mógł także przedostać się za ścianę Central Parku. Iść dalej ${ }^{19}$.

W książce Patricii Churchland zatytułowanej Moralność mózgu. Co neuronauka mówi o moralności jej autorka wskazuje, że emocje homeostatyczne obejmują uczucia i motywacje ${ }^{20}$. Ważną rolę odgrywają obszary paralimbiczne, złożone ze struktur podkorowych i regulujące reakcje emocjonalne, ciało migdałowate i przegroda - odpowiadające za pracę pamięci (obszar hipokampa), wreszcie obszary korowe, odpowiedzialne za zaangażowanie w interakcje społeczne, w tym odczuwanie m.in. przyjemności, radości, szczęścia, zachwytu (wyspa, ACC, kora oczodołowa-czołowa i boczny płat skroniowy) ${ }^{21}$. Przytoczmy znów fragment z utworu Karpińskiego:

Kartezjusza, op. cit., s. 118-136.

19 W. Karpiński, op. cit., s. 8.

20 P. Churchland, Moralność mózgu. Co mówi neuronauka o moralności?, tłum. M. Hohol, N. Marek, Kraków 2013, s. 76.

${ }^{21}$ A. Raine [et al.], Hippocampal Structural Asymmetry in Unsuccessful Psychopts, „Biological Psychiatry” 2004, No. 552, s. 185-191. Zob. P. Churchland, 
Jestem sobą bardziej niż kiedykolwiek, a zarazem jestem tym parkiem zanurzonym w tym wieczorze, jestem tym miastem odbijającym się we mnie i mnie odbijającym. [...] Wyprawa do Nowego Świata to nie tylko podróż $\mathrm{w}$ przestrzeni, ale też podróże w czasie, lekcja geografii i zarazem lekcja języka. [...] Wyjeżdżając, miałem przekonanie, że to, co potrafię opowiedzieć, jeżeli potrafię, to tylko pierwsza wersja, tylko szkic mapy Ameryki. Zamknąć wrażeń z Central Parku nie umiem. Nie zamknęły się przecież. Jeszcze Ameryka nie została oswojona, jeszcze powroty dają radość, trwa pamięć, a wyobraźnia wybiega naprzód. Jeszcze nie koniec podróży ${ }^{22}$.

Według Churchland ocena przyszłych zdarzeń kształtowane jest przez sygnały płynące $z$ układu walencyjnego, który jest samym rdzeniem bycia i odpowiada za życie w społeczeństwie ${ }^{23}$. Karpiński pisze z kolei:

Amerykański pobyt był szkołą czucia i myślenia w dziwnym sensie. [...] W Ameryce, zwłaszcza w Nowym Jorku, czas toczy się inaczej. [...] Czas nie odkłada się w zabytkach kultury, w tak ważnych dla nas, nawet gdy sobie tego nie uświadamiamy, zapisach naszego trwania. [...] Miasto jest tu w dużym stopniu zastąpione przez wielki rynek, wymianę kultur, pulsowanie energii ${ }^{24}$.

Środowisko na różne sposoby pozostawia niezatarty ślad w umyśle człowieka. Jednym $\mathrm{z}$ nich jest stymulacja aktywności neuronowej w oku, uchu, niezliczonych zakończeniach nerwowych. Zakończenia nerwowe wysyłają sygnały do określonych „bram” (rejonów wejściowych) mózgu, którymi są wczesna kora wzrokowa, słuchowa, somatyczna itp. Wszystkie części wczesnej kory czuciowej (wczesna kora wzrokowa, wczesna kora słuchowa itp.) tworzą obszary, pomiędzy którymi dochodzi do intensywnej wymiany sygnałów. Jak podkreśla bohater utworu W Central Parku:

W San Francisco, Stanford, Berkeley czułem się swobodniej niż gdziekolwiek w Stanach, ale zacząłem podejrzewać, że była to podstępna swoboda. Biblioteki zdają się mieć wszystkie książki, muzea są zbyt obszerne, a świat zewnętrzny przyciąga i rozprasza uwagę wciąż nowymi urokami. Tyle rzeczy jest równie dostępnych, równie ważnych. Świadomość rozbiega się

op. cit., s. 76 .

22 W. Karpiński, op. cit., s. 38.

23 A. Raine, op. cit., s. 79.

24 W. Karpiński, op. cit., s. 38. 
w rozmaite strony. Wciąż nowe zjawiska domagają się zrozumienia. Gdzie znaleźć punkt oparcia, język zdolny to ująć, pamięć władną to zapisać? Czyżby dlatego młodzi Amerykanie, zwłaszcza tu, w Kalifornii, przeżywali ostre kryzysy tożsamości, stale kwestionowali autentyczność postaw? Czy dlatego Zachodnie Wybrzeże jest szczególnie podatne na nowe gnozy, rodzi nowe religie? [...] Czułem, jak język traci siłę oporu, nie zmaga się ze światem, staje się rozluźniony, mglisty. Nie usiłuje nazwać tego, co widzą oczy. Między jednym widokiem a drugim kurtyna, potok wrażeń pozbawiony pamięci, nieodkładający się w umyśle ${ }^{25}$.

Pierwszym zastosowaniem obrazowego zapisu relacji człowiek - obiekt jest informowanie podmiotu o tym, co się dzieje i jaka jest relacja pomiędzy podmiotem a obrazami przedmiotów. „Uczucie, że się wie”26, jest początkiem odpowiedzi. Odbieranie sygnałów z otaczającego świata, transformacja ich w obrazy i zapisywanie w pamięci, a później odtwarzanie rozpoczyna proces samorozumienia. Powoduje to zwrócenie jeszcze większej uwagi na przedmiot-przyczynę. Świadomość jest rozszerzona o proces czuwania i koncentrowania uwagi na danym obiekcie. Oba procesy przyczyniają się do przetwarzania obrazów o danej treści i udoskonalają planowane reakcje. Interakcja podmiotu $\mathrm{z}$ danym przedmiotem potęguje szansę wejścia $\mathrm{w}$ relacje $\mathrm{z}$ innymi przedmiotami. Podmiot jest przygotowany na kolejne spotkania i interakcje. Wynikiem tego jest większa czujność, ostrzejsza uwaga i wyższa jakość przetwarzania obrazów:

Zacząłem rozumieć pułapkę skrytą w pięknie Kalifornii, wyzwanie ledwie uchwytne w ciepłym powietrzu, w łagodnej linii wzgórz, w szumie fal Zatoki San Francisco. Może najwyraźniej zabrzmiało to amerykańskie kuszenie podczas przejażdżki statkiem po zatoce, gdy zachodzące słońce wyrabiało przedziwne rzeczy z sylwetą miasta. Purpurę cięła ciemna, bezkresna linia Golden Gate Bridge. Naprzeciw wyrastały załomy zielonej skarpy Sausalito. [...] Znalazłeś się naprawdę poza granicami twojego języka. Trzeba innych słów, aby słońce świecące nad szerokim horyzontem Teksasu nie zanikło po zamknięciu oczu, aby skały Wielkiego Kanionu nie zagubiły płynnej gamy czerwieni, którą przyniósł im świat. [...] Trzeba dokonać innych czarów, których właśnie czystym wysiłkiem woli czy intelektu spełnić nie zdołasz.

25 Ibidem, s. 43.

26 A. Damasio, Tajemnica świadomości, op. cit., s. 196. 
Ale i pokorna otwartość tego nie stworzy. Nie narzucaj widokom ram, bo nawet nie dostrzeżesz tego, co cię otacza, nowego świata nie dojrzysz. Postaraj się wyszukać odpowiednie ramy, bo inaczej nie utrwalisz w sobie tego widoku, nawet jeżeli przez chwilę go odczujesz. Rozpłyną się twarze. Zbledną kolory. Zaginą perspektywy ${ }^{27}$.

To właśnie interferencja pomiędzy podmiotowością a przestrzenią uaktywnia pamięć bohatera, jego doświadczenie bycia-w-świecie. Zanurzenie się w metropolis, rozpoznawanie własnej sytuacji w przestrzeni jest paralelne wobec zmian, jakie zachodzą w jego psychice: „Wyprawa do Nowego Świata to nie tylko podróż w przestrzeni, ale też podróże w czasie..."28. Obrazy Ameryki, jakie powstały w umyśle bohatera, powstały z ruchu ku przejściom - od miasta realnego do wyobrażonego, od teraźniejszości do przeszłości, od kondycji spacerowicza do figury artysty, od percepcji świata zewnętrznego do doświadczeń i przeżyć w sferze psychicznej. Blisko zespolone ze sobą obszary kory stanowią podstawę topograficznie zorientowanych reprezentacji umysłowych, czyli źródło pojawiających się w umyśle obrazów. Organizm bohatera konsekutywnie oddziałuje na otoczenie poprzez ruchy swojego ciała oraz instrument głosu sterowany przez korę obszarów M1, M2, M3 (jest to obszar kory ruchowej: w rejonie M1 leży tzw. pas ruchowy, rysowana jest na nim często sylwetka człowieka; rejon M2 to suplementarna okolica ruchowa, wewnętrzna część rejonu 6; rejon M3 ukryty jest w głębi bruzdy obręczy) z pomocą kilku ruchowych jąder podkorowych ${ }^{29}$. W mózgu bohatera występują rejony, do których nieprzerwanie docierają sygnały z ciała właściwego oraz jego narządów zmysłowych. Obszary wejściowe są od siebie oddzielone i nie komunikują się ze sobą bezpośrednio:

Kiedy świat zewnętrzny jest tak nowy, oczy, kiedy nie prowokują do oporu i narkotyzują umysł pokusą konsumpcji wrażeń, wygodnej i czczej, wówczas tym większego trzeba wysiłku, aby ożywić i umocnić władzę mowy: nauczyć się nazywać własny świat, a więc zdobyć i świat, i narzędzia nazywania, osiągnąć suwerenność, żywą obecność w kulturze. To przecież rola sztuki współczesnej - zburzyć dawne przeszkody, zbudować nowe mitologie,

27 W. Karpiński, s. 43-44.

28 Ibidem, s. 38.

29 Zob. A. Damasio, Błąd Kartezjusza, op. cit., s. 113. 
ułatwić porozumienie $\mathrm{z}$ otaczającym społeczeństwem [...], nowoczesna sztuka chciałaby stworzyć i nowe znaki, i nowe oazy wolności ${ }^{30}$.

W mózgu podmiotu musi zaistnieć synchronizacja w działaniu poszczególnych ośrodków w odpowiednim do tego czasie, tak aby z płynących informacji mogły powstać obrazy i doszło do rozpoczęcia procesu rozumowania oraz podejmowania odpowiednich decyzji. Zespolenie w czasie wymaga udziału operatywnych mechanizmów uwagi, a także pamięci operacyjnej.

Bohater utworu Karpińskiego przybywa do Stanów Zjednoczonych, spaceruje po ulicach Nowego Jorku i San Francisco, obserwuje ludzi, uczestniczy w koncercie w Central Parku, słucha muzyki, czyta wiersze. Doznaje wrażeń zmysłowych, a w jego umyśle powstają obrazy o różnych modalnościach czuciowych. Powstające w ten sposób obrazy nazywane są obrazami percepcyjnymi. Bohater Karpińskiego podejmuje refleksje nad wysłuchaną muzyką w Metropolitan Opera, oglądanym obrazem Davida Hockney’a, przeczytanym wierszem Dar Vladimira Nabokova, a każda z tych myśli tworzy obrazy, które w różnym stopniu mogą opierać się na dźwiękach, barwach, wypowiedzianych i niewypowiedzianych słowach.

Obrazy, które przywołuje pamięć rzeczy minionych, nazywane są obrazami przywoływanymi, w odróżnieniu od tych budowanych bezpośrednio na podstawie informacji zmysłowej. Kiedy bohater planuje różne czynności, w jego umyśle powstają obrazy obiektów i ruchów fikcyjnych, które również zapisują się w pamięci:

Artystyczne przypuszczenie staje się realnością, rozszerza pole widzenia, wzbogaca rzeczywistość, wyzwala - jest nie tylko to, co jest, lecz również to, co może być. Ukazać to, co być może, znaczy poszerzyć sferę istnienia. Czy dzieje się tak zawsze? Gdzieś, kiedyś - na różnych stopniach naiwności czy komplikacji - dochodzimy do starego pytania: jakie są zasady uwierzytelniania fikcji literackiej, jakie są kryteria artystycznej prawdy? Czy ważny jest dźwięk głosu, polot wyobraźni, a za treść autor nie ponosi odpowiedzialności? [...] Czy tylko tyle, że mogę ze zwojów imaginacji wysnuć wszystko, a o tożsamości dzieła $\mathrm{z}$ twórcą świadczy jedynie blask metafor, tempo stylu, misterność kompozycji, bez względu na to, w jaką opowieść układałyby się te fantazje? ${ }^{31}$

30 W. Karpiński, op. cit., s. 44.

31 Ibidem, s. 66-67. 
W ten sposób u bohatera tworzy się raczej pamięć potencjalnej przyszłości niż faktycznej przeszłości. Za proces ten odpowiada skomplikowana neuronowa maszyneria percepcji, pamięci i rozumowania. Powstawanie takich obrazów indukowane jest przez zdarzenia ze świata zewnętrznego przy pomocy pamięci długotrwałej ${ }^{32}$. Są to obrazy percepcyjne, które opierają się bezpośrednio na reprezentacjach neuronowych, zorganizowanych topograficznie. Inwencja ich tworzenia rodzi się we wczesnej korze czuciowej podczas rozmyślania i refleksji bohatera. Obrazy nie są przechowywane w formie podobizn przedmiotów, wydarzeń, słów czy zdań. Gdy bohater odtwarza z pamięci jakiś obiekt, to nie otrzymuje jego dokładnego obrazu, lecz tylko pewną interpretację:

Błyskawiczne zmiany w otoczeniu zdawały się sprzyjać jasności spojrzenia. Ale nie skupieniu uwagi, nie przyswojeniu wrażeń przez pamięć: te pozostawały rozproszone, oddzielone, niekontaktujące się ze sobą, a tylko rywalizujące (lecz gdzie znaleźć miarę?) oślepiającą wspaniałością i różnorodnością. Kilka dni spędzonych w Princeton i w Waszyngtonie wśród przyjaciól, w bibliotece i w muzeach, było dobrym wstępem do podróży przez Amerykę ${ }^{33}$.

Damasio stwierdza, że system wzrokowy sekwencyjnie koduje poszczególne części obiektów, zaś dopiero w pamięci są one łączone w jedną całość. Karpiński pisze:

Podczas wieczornego przedstawienia w Central Parku wyobraźnia uległa dziwnemu spotęgowaniu. Wyzwolona, posuwała się przecież ku realnemu światu. Pobudzała wspomnienia niedawnych przeżyć, całą dotychczasową podróż, i nadawała im nowe perspektywy. W nagłym impecie obrazów i myśli jeszcze niezamarłych w formuły, jeszcze swobodnie przenoszących się z jednego obszaru na inny [...], wciąż narzucała mi się pewna książka, którą odczytywałem wyobraźnią między kartami książki realnej. [...] Tkwiła korzeniami w mojej pamięci. Przyglądałem się korowodowi postaci. Przepływały wraz z muzyką. Mówiły do mnie, a raczej były własnym sensem, wreszcie widocznym ${ }^{34}$.

\footnotetext{
32 A. Damasio, Błąd Kartezjusza, op. cit., s. 122-124.

33 W. Karpiński, op. cit., s. 42.

34 Ibidem, s. 11-12.
} 
Spostrzeganie wzrokowe bohatera (widzenie) i wyobraźnia wizualna wyznaczają dwa kierunki przebiegu procesów percepcyjnych: oddolny i odgórny. Spostrzeganie wzrokowe bohatera jest procesem inicjowanym oddolnie przez bodziec pobudzający receptory wzrokowe i w pierwszej fazie przebiega na szlaku percepcyjnym w trybie aferentnym. Z kolei jego wyobraźnia jest procesem inicjowanym odgórnie przez określoną potrzebę lub cel zachowania i w pierwszej fazie przebiega na szlaku percepcyjnym $\mathrm{w}$ trybie zwrotnym. Kluczowym elementem, który zespala procesy odpowiedzialne za spostrzeganie wzrokowe i wyobraźnię, jest pierwotna hipoteza percepcyjna, sformułowana we wczesnych etapach szlaku wzrokowego. Pierwotna (szkicowa) hipoteza percepcyjna definiuje kontur spostrzeganego/ wyobrażonego przedmiotu lub sceny z wyróżnieniem przez pole percepcyjne figury i tła. Hipoteza percepcyjna jest formułowana na podstawie trwale przechowywanych w pamięci kształtów spostrzeganych przedmiotów. Zadaniem kolejnych modułów na szlaku wzrokowym między pierwszorzędową korą wzrokową a korą czołową mózgu jest dopełnienie pierwotnej hipotezy percepcyjnej danymi dotyczącymi morfologii, ruchu, lokalizacji i kontekstu przestrzennego spostrzeganego i wyobrażonego obiektu ${ }^{35}$. Czołowa kora mózgu jest systemem odpowiedzialnym za synchronizację i kontrolę przebiegu procesów poznawczych bohatera, które realizują jego aktualne potrzeby motoryczne i komunikacyjne:

Gdy patrzyłem na Okno w Luwrze, na inne rysunki i ryciny, wydało mi się, że język artystyczny tych dzieł jest nie tylko własnością autora, mówi do patrzącego i patrzący mówi dalej tym językiem, zostaję zaproszony do podróży. Opowiadać o niej? Przeszedłem przez szyby na akwaforcie. Droga, jaką odbyłem, wydała mi się istotna nie tylko do zrozumienia jego twórczości ${ }^{36}$.

Procesy wyobrażeniowe są integralną częścią cyklu percepcyjnego, co bohater konsekwentnie potwierdza:

${ }_{35}$ Zob. P. Francuz, Teoria wyobraźni Stephena Kosslyna. Próba interpretacji, [w:] Obrazy w umyśle. Studia nad percepcja i wyobraźnią, red. idem, Warszawa 2007, s. 179-183.

36 W. Karpiński, op. cit., s. 62. 
Twórczość jako szkoła wyobraźni, tak chyba widział Nabokov zadanie artysty. Odsłaniać (domyślać, dopełniać) modalności egzystencji; odnosić zwycięstwo nad materialną biernością trybu oznajmującego, nad wulgarnym determinizmem trybu rozkazującego, budując (urealniając przez uświetnienie) złożony system trybu warunkowego ${ }^{37}$.

W tym przypadku możemy mówić o teorii, którą w 2002 roku Melanie Green i Timothy Brock nazwali teorią TIM (Transporation-Imagery Model of Narrative Persuasion), czyli model wyobrażeniowego przenoszenia się w narrację, która wpływa na zachowanie i postawę odbiorcy. Karpiński pisze:

W zwierciadle dzieła odbity zostaje wizerunek artysty szukającego dzieła. Patrzący, czytający, słuchający, zaproszony jest do twórczości: ma z płynnych układów formalnych zrekonstruować duchowy świat twórcy. Czasem prowadzi to do rozkołysania wyobraźni, ale same utwory stają się bardziej anemiczne: ze wszystkiego można wyprowadzić wszystko. [...] Ale właśnie w chwili zawieszenia nie pamiętałem o pięknie słów. Słowa przebywały daleko. Chwila zapomnienia, aby lepiej pobudzić pamięć. Chwila zawieszenia, oczyszczenia pamięci, przygotowania wyobraźni ${ }^{38}$.

Model wyobrażeniowego przejścia w narrację można streścić w kilku punktach: 1. jest to narracja, która pobudza wyobraźnię i angażuje odbiorcę; 2. odbiorca zostaje „pochłonięty” przez narracyjny świat i jakby przez chwilę dystansuje się wobec swojej realności; 3. proces transformacji zależy od zespołu cech odbiorcy, jak również od poziomu kunsztu artystycznego oraz tego, czy narracja jest oparta na faktach, czy jest wytworem wyobraźni (fikcyjna); 4. przekaz narracyjny zależy od kontekstu (kulturowego) ${ }^{39}$.

Dawałem się unosić muzyce. Cały byłem swobodną uwagą. W dziwnym podnieceniu - to momenty od dawna wybrane, gdy nagle w rytm myśli zaczynam biec ulicą bądź uśmiecham się z odpowiedzi jednej z półwymyślonych osób - starałem się zapamiętać obrazy, nie tamując ich przepływu.

${ }^{37}$ Ibidem, s. 66.

38 Ibidem, s. 65 i 161-162.

39 M.C. Green, T.C. Brock, In the Mind's Eye: Transporation-Imagery Model of Narrative Persuasion, [w:] Narrative Impact, op. cit., s. 316-317; P. Fortuna, Zmiana przekonań w wyimaginowanym świecie. Rola wyobraźni w perswazji narracyjnej, [w:] Obrazy w umyśle, op. cit., s. 251. 
Na tle Central Parku, Nowego Jorku, wszystkich widm, jakie przybyły na ten amerykański festyn, wciąż powracała wyszukana w fikcyjnej autobiografii przysięga-wyznanie:

Love only is fanciful and rare;

What from the distance of a dream steals through;

What knaves condemn to death and fools can't bear.

To fiction be as your country true.

To z Daru Nabokova. Dar? Wieczór w Central Parku był darem i pojawieniem się tylu imaginacyjnych rozmówców ${ }^{40}$.

W powyższym fragmencie można zaobserwować, jak działa wyobraźnia motoryczna, dzięki której mózg aktywuje plan ruchowy i kieruje jego rozwojem poprzez wewnętrzne informacje zwrotne. Istnieje duże podobieństwo na poziomie neuronalnym między wykonaniem czynności a jej obserwacją lub wyobrażeniem. Według badaczy wyobraźnia motoryczna umożliwia rozpoznanie ruchów i rozumienie zachowania, może także brać istotny udział w odczytywaniu intencji innych ludzi ${ }^{41}$.

Język jest warunkiem istnienia i wspomagania pamięci - aby ta mogła funkcjonować, musi uczestniczyć w procesie komunikacji. Erll w wywiadzie zatytułowanym Pamięć, język a dyskursy medialne ${ }^{42}$ podkreśliła, że bardzo istotną kwestią jest ścisły związek między językiem i pamięcią indywidualną, szczególnie w sferze autobiograficznych systemów pamięci. Obraz przeszłości nie jest tylko repetycją tego, co było. Pamięć ma charakter twórczy, konstruuje, komasuje i transponuje przeszłość. Pisze Karpiński:

Wyjątkowość tych momentów wycina je z obszaru rzeczywistości, zamyka w sobie. Czasem jednak sztuka łączy się z naszą genealogią, przemawia do

${ }^{40}$ W. Karpiński, op. cit., s. 12-13.

${ }_{41}$ Zob. B. Bałaj, Umysłowa symulacja z wykorzystaniem wyobraźni motorycznej. Przegląd teorii badań, [w:] Obrazy w umyśle, op. cit., s. 231-234. Por. G. Rizzolatti, L. Fogassi, V. Gallese, Cortical Mechanisms Subserving Object Grasping, Action Understanding, and Imitation [w:] The Cognitive Neurosciences, ed. M.S. Gazzaniga, Cambridge (MA) 2004, s. 427-440.

${ }^{42}$ Pamięć, język a dyskursy medialne - rozmowa z prof. Astrid Erll, prof. Bożena Witosz i prof. Robertem Traba, „Tekst i Dyskurs / Text und Diskurs” 2014, nr 7, s. 11-19. 
naszego doświadczenia, choćbyśmy nie potrafili przełożyć jej słów na język codziennego życia. Ta sztuka otwiera przed wrażliwością wiele wymiarów. Wyprowadza poza ograniczenia teorii, stwarza pole intensywnego odczuwania. Stąd świadomość jednoczesnej obecności w kilku miejscach, przeżywania wielu spraw. Znikają bariery wznoszone przez nas samych i przez innych. Dotykamy pulsującej rzeczywistości. Świat odbija się w pamięci wielowymiarowymi zdjęciami ${ }^{43}$.

Często bodźcem do powstawania obrazów jest przypominanie przez bohatera różnych wydarzeń z przeszłości, w których uczestniczył: „A więc mów, pamięci, wspominaj widzenia tamtego wieczoru, opisuj podróże. Pamiętam wystawę Hockneya, która najechała na mnie w zaśnieżonym New Haven. Radość widzenia i otwarcia oczu. Sztuka ożywała, dotykała świata. Uczyła mowy"44. Obrazy łączą człowieka ze światem, z drugim człowiekiem, widza $\mathrm{z}$ artystą, czytelnika $\mathrm{z}$ pisarzem:

Pamiętam zapach trawy, smak jedzenia. Widzę intensywną świetlistość żółtej tarczy księżyca zawieszonego nad drapaczami Wschodniej Strony. Neonowy termometr notuje zbawcze ochłodzenie. Coraz przyjemniej oddychać. Słyszę arię księcia. Jestem w tej muzyce. Jestem tu. A jednocześnie jakbym śledził równolegle kilka filmów. Oglądam zmieniające się widoki. Nakładają się, lecz zachowują wyrazistość. Mówią do mnie, rozmawiają we mnie. Jestem sobą bardziej niż kiedykolwiek, a zarazem jestem tym parkiem zanurzonym w tym wieczorze, jestem tym miastem odbijającym się we mnie i mnie odbijającym ${ }^{45}$.

Równolegle do procesu powstawania „umysłowych wzorów” danego obiektu rodzi się poczucie „Ja” u bohatera. Za ten proces odpowiada świadomość rdzenna. Drugi typ świadomości to świadomość rozszerzona, podzielona na różne stopnie i poziomy, wzbogacona o doświadczenia i przeżycia z przeszłości, rejestrująca wydarzenia chwili obecnej: „Wspaniałość doznań nieraz paraliżuje. Intensywność chwil, odmienna od czasu powszedniego, stanowi wówczas dodatkową kurtynę. Nie styczność wyobraźni, obcość języka. Ten, kto przeżywa, jest osobowością wewnątrz osobowości,

\footnotetext{
43 W. Karpiński, op. cit., s. 8-9.

44 Ibidem, s. 17.

45 Ibidem, s. 9.
} 
wydzielony, odmienny"46. Świadomość rozszerzona korzysta z pamięci konwencjonalnej i roboczej, kiedy u bohatera osiąga najwyższy stopień, zostaje rozszerzona o język:

Niekiedy jednak wyobraźnia odnajduje się i utwierdza w podróży, wyjeżdża z nami, wysyła nas ku światu, ułatwia porozumienie, uczy o innych i o nas samych. Festyn w Central Parku sprzyjał otwarciu i komunikatywności wyobraźni. Od dawna problem podstawowy: uzyskać głos, nauczyć się języka, w którym mógłbym ujmować świat i siebie bez deformacji sensu. Podróże jak dzieła sztuki - są szkołą mowy ${ }^{47}$.

Świadomość rdzenna referuje tylko część bytu, a świadomość rozszerzona - całość. W świadomości rozszerzonej przeszłość i to, co ma nadejść, są odczuwane równolegle z tym, co się dzieje tu i teraz, w przewijających się obrazach. Te dwa rodzaje świadomości odpowiadają dwóm rodzajom „Ja”. „Ja”, które wyłania się ze świadomości rdzennej, to „Ja” rdzenne, wytwór przejściowy, nietrwały, powstający w momencie interakcji z danym obiektem. Jak dowodzi neurobiolog: rdzenne „Ja” uczestniczy w niewerbalnym zapisie drugiego stopnia, który pojawia się, kiedy dany obiekt doprowadza do modyfikacji proto-„Ja” (stanowi pewien rodzaj odniesienia inny niż miejsce przechowywania wiedzy, uczestniczy w procesie odczucia samowiedzy). Odpowiedź reprezentowana przez proto-„„a” jest przekładana organizmowi, ukazywana w formie niewerbalnej narracji, która może zostać przełożona na język. Zespół rdzennego „Ja” może pobudzić dowolny obiekt. W czasie życia zespół przechodzi tylko minimalne zmiany ${ }^{48}$. Drugie „Ja”stabilne, kształtujące tożsamość, określane jest jako „Ja” autobiograficzne, oparte jest bowiem na pamięci autobiograficznej, która powstaje poprzez przywoływanie wspomnień i różnych doświadczeń z przeszłości ${ }^{49}$. Bohater Karpińskiego mówi:

I pamiętałem o tych, którzy uczyli mnie mówić, oprowadzali po rodzinnym języku. Dzięki nim ożywały słowa, dostrzegałem naczynia krwionośne

\footnotetext{
46 Ibidem.

47 Ibidem, s. 9-10.

48 A. Damasio, Tajemnica świadomości, op. cit., s. 187, 212.

49 Ibidem, s. 187.
} 
kultury. Pamiętam spotkanie z Miłoszem w San Francisco, pamiętam inne, przed laty, z Gombrowiczem w Vence. Nie konkretne rozmowy, nie one były ważne, lecz budowanie własnej genealogii, spotkania z ich dziełami, które pozwoliły mi pełniej rozumieć także to miasto, tę podroż $\dot{z}^{50}$.

Pamięć autobiograficzną tworzą niezmienne elementy indywidualnej biografii. Konglomerat wspomnień, które określają tożsamość podmiotu, jest reaktywowany przez etalon neuronowy i kiedy zaistnieje taka konieczność, ukazuje się w postaci obrazów. Każdy restytuowany ślad jest rozpoznawany i interpretowany, przyczyniając się do powstawania "Ja" autobiograficznego ${ }^{51}$ : świadomość rozszerzona wykracza poza obszar „tu i teraz”. Teraźniejszość jest kształtowana przez przeszłość. Świadomość rozszerzona obejmuje całe życie jednostki, wraz z przeszłością i teraźniejszością tworzy tzw. treść autobiograficzną.

$* * *$

Autor Twarzy wskazuje na ważną rolę pamięci w procesie budowania tożsamości człowieka - nie tylko jako źródło wiedzy, lecz także swoiste doświadczenie sprzężone ze strukturalnym byciem człowieka w czasie. Antonio Damasio takie sytuacje w życiu bohatera nazywa opowiadaniem bez słów. Człowiek nabywa wewnętrzną niewerbalną wiedzę o tym, że przeobraża się pod wpływem transponowanych informacji z danego obiektu, który znajduje się w określonym kontekście czasoprzestrzennym. Każde wydarzenie z przeszłości decyduje o tym, kim człowiek jest dzisiaj; przeszłość tworzy „Ja” człowieka, nieustannie wzbogacając je o nowe aspekty. Na koniec rozważań przywołam ważną myśl Cornelißena na temat funkcji pamięci i jej roli w budowaniu obrazu człowieka: termin „kultura pamięci” oznacza również, że wszystkie formy przywłaszczenia wspomnień z przeszłości są ważne $^{52}$ - teksty, obrazy, zdjęcia, zabytki, budynki, festiwale, jak również symboliczne i mityczne formy ekspresji, porządki mentalne (rozumiane

${ }^{50}$ W. Karpiński, op. cit., s. 18.

51 A. Damasio, Tajemnica świadomości, op. cit., s. 187.

52 W. Hardtwig, Vorwort, [w:] Geschichtskultur und Wissenschaft, Hrsg. von W. Hardtwig, München 1990, s. 7-11; J. Rüsen, Was ist Geschichtskultur? Überlegungen zu einer neuen Art, über Geschichte nachzudenken, [w:] Historische Faszination. Geschichtskultur heute, Hrsg. von K. Füßmann, H.T. Grüttner, J. Rüsen, 
jako przedmioty historii pamięci), o ile przyczyniają się do powstawania kulturowych obrazów siebie ${ }^{53}$. Pamięć wpływa na zachowanie i sposób bycia człowieka w świecie. Zapisuje w świadomości doświadczenia i indywidualne przeżycia, warunkuje kształtowanie „Ja” człowieka i poczucie tożsamości.

Karpiński, przypominając sobie różne obrazy z przeszłości, ułożył jej historię, jego narracja ma charakter porządkujący i wartościujący. Damasio w książce Tajemnice świadomości przywołał fragment z Notes on the Reality of the Seld Jorie Grahama na temat tożsamości człowieka:

Pytanie, kim byłem, dręczyło mnie. Sądziłem już, że nie zdołam odnaleźć obrazu tej osoby, którą byłem: wszystko umknęło. To, co zaledwie w sobie dojrzałem, ginęło znów niewidoczne. A jednak czułem, że chwila, w której dostąpiłem praw, była tą, w której objawiłem się sam sobie - chwilą, w której zacząłem żyć - stopniowo - krok po kroku - nieubłaganie. Uważaj, ach, co czynisz! Czy chcesz trwać w ukryciu, czy wyjść na światło? ${ }^{54}$

To światło jest podstawowym elementem konstruowanych i przypominanych obrazów przez Wojciecha Karpińskiego. Światło doprowadza go do pełnej świadomości, do prawdy o sobie, o drugim człowieku, o świecie.

\section{Bibliografia}

Aleida Assmann, Cultural Memory and Western Civilization. Functions, Media, Archives, Cambridge University Press, Cambridge 2011.

Frederic Bartlett, Remembering: a Study in Experimental and Social Psychology, Cambridge UP, Cambridge 1954.

Patricia Churchland, Moralność mózgu. Co mówi neuronauka o moralności?, tłum.

M. Hohol, N. Marek, Copernicus Center Press, Kraków 2013.

The Cognitive Neurosciences, ed. M.S. Gazzaniga, MIT Press, Cambridge (MA) 2004. Christoph Cornelißen, Erinnerungskulturen. Version 2.0, 22.10.2012, Docupedia-Zeitgeschichte. Begriffe, Methoden und Debatten der zeithistorischen Forschung, DOI: 10.14765/zzf.dok.2.265.v2.

Köln 1994, s. 3-26; Geschichtskultur. Theorie - Empirie - Pragmatik, Hrsg. von B. Mütter, B. Schönemann, U. Uffelmann, Weinheim 2000.

53 Zob. C. Cornelißen, Erinnerungskulturen, op. cit.

54 A. Damasio, Tajemnica świadomości, op. cit., s. 9. 
Christoph Cornelißen, Historische Identitätsbildung im Bindestrichland Nordrhein-Westfalen (= Schriften der Stiftung Bibliothek des Ruhrgebiets, Bd. 26); Klartext Verlag, Essen 2008.

Christoph Cornelißen, Was heißt Erinnerungskultur? Begriff - Methoden Perspektiven, „Geschichte in Wissenschaft und Unterricht” 2003, heft 54.

Christoph Cornelißen, Stefan Fisch, Annette Maas, Grenzstadt Straßburg: Stadtplanung, kommunale Wohnungspolitik und Öffentlichkeit 1870-1940 (= Saarbrücker Studien zur interkulturellen Kommunikation, Bd. 2), Röhrig Universitätsverlag, St. Ingbert 1997.

Antonio Damasio in conversation with Manuel Castells [wywiad], 6.02.2017, Central Library, Los Angeles.

Antonio Damasio, Błąd Kartezjusza. Emocje, rozum i ludzki mózg, tłum. M. Karpiński, Rebis, Poznań 1994.

Antonio Damasio, Conference. Art and the New Biology of the Mind [wykład], 24.03.2006, The Italian Academy (Columbia University).

Antonio Damasio, Creativity, Imagination and Innovation [wykład], 13.01.2014, Ross Institute Summer Academy, East Hampton (NY).

Antonio Damasio, Dziwny porzadek rzeczy. Życie, uczucia i tworzenie kultury, tłum. A. Jankowski, Rebis, Poznań 2018.

Antonio Damasio, Jak umysł zyskał jaźń. Konstruowanie świadomego mózgu, tłum. N. Radomski, Rebis, Poznań 2012.

Antonio Damasio, Tajemnica świadomości. Ciało i emocje wspóttworza świadomość, tłum. M. Karpiński, Rebis, Poznań 2000.

Antonio Damasio, W poszukiwaniu Spinozy: radość, smutek i czujący mózg, tłum. J. Szczepański, Rebis, Poznań 2003.

Antonio Damasio, What is the Strange Order of Things? [wykład], 31.07.2018, Copernicus Center for Interdisciplinary Studies.

Antonio Damasio, Hanna Damasio, Dziwny porzadek rzeczy. Homeostaza, uczucia i powstawanie kultur [wykład], 13.09.2017, Copernicus Center for Interdisciplinary Studies.

Astrid Erll, Cultural Memory Studies: An Introduction, [w:] Media and Cultural Memory, ed. A. Erll, W. de Gruyter, Berlin - New York 2008.

Astrid Erll, Kultura pamięci. Wprowadzenie, tłum. A. Teperek, WUW, Warszawa 2018

Frankfurt Memory Studies Platform, http://www.memorystudies-frankfurt.com. 
Klaus Füßmann, Heinrich T. Grüttner, Jörn Rüsen (Hrsg.), Historische Faszination. Geschichtskultur heute, Böhlau, Köln 1994.

Geschichtskultur. Theorie - Empirie - Pragmatik, Hrsg. von Bernd Mütter, Bernd

Schönemann, Uwe Uffelmann, Deutscher Studien Verlag, Weinheim 2000. Wolfgang Hardtwig, Vorwort, [w:] Geschichtskultur und Wissenschaft, Hrsg. von W. Hardtwig, Deutscher Taschenbuch Verlag, München 1990.

Hans G. Hockerts, Zugänge zur Zeitgeschichte. Primärerfahrung, Erinnerungskultur, Geschichtswissenschaft, [w:] Verletztes Gedächtnis. Erinnerungskultur und Zeitgeschichte im Konflikt, Hrsg. von K.H. Jarausch, M. Sabrow, Campus Verlag, Frankfurt am Main 2002.

Wojciech Karpiński, W Central Parku, Fundacja „Zeszytów Literackich”, Warszawa 2010.

Tomasz Majewski, Kinematyka pamięci: Aby Warburg i Jean-Luc Godard, https://www.academia.edu/3776503/Kinematyka_pami\%C4\%99ci _Aby_Warburg_i_Jean_Luc_Godard.

Philippe-Alain Michaud, Aby Warburg and the Image in Motion, transl. S. Hawkes, Zone Books, New York 2004.

Jeffrey Olick, Joyce Robins, Social Memory Studies. From „Colective Memory” to the Historical Sociology of Mnemonic Practices, "Annual Review of Sociology" 1989, Vol. 24.

Obrazy w umyśle. Studia nad percepcją i wyobraźnią, red. P. Francuz, WN Scholar, Warszawa 2007.

Adrian Raine [et al.], Hippocampal Structural Asymmetry in Unsuccessful Psychopts, „Biological Psychiatry” 2004, No. 552.

Adam Rajewski, Rozważanie na temat Assmanowskiej teorii pamięci, „Rocznik Antropologii Historii" 2013, R. 3, nr 1(4).

Daniel Schacter, Searching for Memory: The Brain, the Mind, and the Past, Basic Books, New York 1996.

\section{American Images in the Memory of Wojciech Karpiński in the Context of Antonio Damasio's Neurological Research}

In this article, I describe the way in which images come into being in the mind of the protagonist of the book $W$ Central Park [In Central Park] by Wojciech Karpiński. I analyze the protagonist's behavior in the perspective of Antonio Damasio's neurobiological research. Memory is one of the factors 
that participate in the creation of images in the artist's mind. It is a dynamic phenomenon that collects memories evoked by various stimuli. It also participates in the creation of the autobiographical 'self' of the protagonist.

Keywords: images, memory, imagination, neuroscience, culture, literature 